\title{
AKTY ULTRA VIRES W ŚWIETLE ODPOWIEDZIALNOŚCI ORGANIZACJI MIEDZYNARODOWYCH
}

\section{UWAGI WSTEPNE}

Problematyka odpowiedzialności międzynarodowej organizacji międzynarodowych jest współcześnie przedmiotem dużego zainteresowania licznych specjalistów zajmujących się prawem organizacji międzynarodowych. Zasadniczo uzasadniony wydaje się pogląd M. Lachsa, że: „Organizacje międzynarodowe generalnie wciąż testują i dopasowują dokumenty konstytucyjne, które same wydały, czy nadają się do podwójnego celu - efektywnego podejmowania uchwał i ochrony przed nierównowagą lub nadużyciem tak jak pomiędzy członkami lub kompetentnymi organami" ". Zdaniem J. A. Froweina, należy uwzględnić fakt, że „Jest względnie mało organizacji międzynarodowych, które zapewniaja zorganizowany system pozwalający testować prawowitość uchwał" ${ }^{2}$. I. Brownlie konstatuje, że zgodnie $\mathrm{z}$ ogólną zasadą powszechnego prawa międzynarodowego każde naruszenie zobowiązania, które ciąży na określonym podmiocie prawa międzynarodowego, polegające na działaniu lub zaniechaniu, prowadzi do odpowiedzialności ${ }^{3}$. Nie sposób zarazem nie zgodzić się z tezą G. Schwarzenbergera, który traktuje naruszenie zobowiązania międzynarodowego jako akt międzynarodowo bezprawny, a więc działanie lub zaniechanie dokonane, dobrowolne, nieusprawiedliwione i odnoszące się do podmiotu prawa międzynarodowego ${ }^{4}$. Z kolei W. Czapliński słusznie uważa, że: „Gwałtowny rozwój praw człowieka w ostatnich dekadach wywarł znaczący wpływ na różne dziedziny prawa pośrednio wpływające na pozycję jednostek w prawie międzynarodowym. Niektóre z tych oddziaływań znalazły już swój wyraz normatywny i/lub były szeroko dyskutowane przez doktrynę prawa międzynarodowego. Inne stanowiły przedmiot zainteresowania doktryny w zdecydowanie mniejszym zakresie. Do tej drugiej kategorii należą zagadnienia odpowiedzialności międzynarodowej państw za naruszenia praw człowieka" ${ }^{5}$. Warto przy tym dodać, że

\footnotetext{
${ }^{1}$ M. Lachs, The Decision-Making Powers and the Judiciary within the United Nations, w: P. Fisher et al. (red.), Völkerrecht und Rechtsphilosophie - Internationale Festschrift für Stephan Verosta, Berlin 1980, s. 389 (tłum. M.R.).

${ }^{2}$ Zob. J. A. Frowein, The Internal and External Effects of Resolutions by International Organizations, ,Zeitschrift für ausländisches Öfftentliches Recht und Völkerrecht” 49, 1989, s. 781.

${ }^{3}$ I. Brownlie, Principles of Public International Law, Oxford 2008, s. 422.

${ }^{4}$ Zob. G. Schwarzenberger (red.), A Manual of International Law, t. 1, London 1960, s. 163-164.

${ }^{5}$ Zob. W. Czapliński, Odpowiedzialność państwa członkowskiego za akty organizacji międzynarodowej, dostępny na: http://www.korporacje.com/index.php (20.04.2010).
} 
skoro brak przejrzystości reguł rządzących odpowiedzialnością międzynarodowa organizacji międzynarodowych, konieczne wydaje się dokonanie nich wnikliwego przeglądu.

Ze względu na znaczną różnorodność koncepcji na temat wspomnianego zagadnienia ${ }^{6}$, w niniejszym opracowaniu zostaną omówione najistotniejsze kwestie dotyczące między innymi przesłanek odpowiedzialności organizacji międzynarodowych za akty ultra vires, przykłady przekroczenia kompetencji przez organizacje międzynarodowe oraz zagadnienia interwencji humanitarnej w kontekście odpowiedzialności organizacji międzynarodowych.

\section{PRZESŁANKI ODPOWIEDZIALNOŚCI ORGANIZACJI MIEDZYNARODOWYCH ZA AKTY ULTRA VIRES}

Prawo międzynarodowe zobowiązuje podmioty tego prawa, aby przestrzegały one ustanowionych norm. Notabene źródłem odpowiedzialności prawnomiędzynarodowej organizacji międzynarodowej jest uczynienie aktu sprzecznego $\mathrm{z}$ prawem międzynarodowym, polegające na działaniu lub zaniechaniu ze strony tej organizacji, która w taki sposób narusza swoje zobowiązanie w stosunku do innego podmiotu prawa międzynarodowego. Zatem odpowiedzialność za naruszenie prawa międzynarodowego można traktować jako stosunek prawny powstający pomiędzy podmiotem prawa międzynarodowego, który doprowadził do naruszenia prawa, a tym, którego dobra naruszono ${ }^{7}$. Niemniej nie mogła zostać podana w wątpliwość merytoryczna zasadność kompleksowej kodyfikacji i permanentnego rozwoju międzynarodowego porządku prawnego regulującego odpowiedzialność międzynarodową. Należy w tym miejscu wskazać warunki odpowiedzialności organizacji międzynarodowych ${ }^{8}$.

Po pierwsze - istotne jest istnienie podmiotowości prawnomiędzynarodowej danej organizacji (możliwa jest również dorozumiana podmiotowość na drodze wniesienia roszczenia w stosunku do danej organizacji).

\footnotetext{
${ }^{6}$ D. Alland, Countermeasures of General Interest, „European Journal of International Law” 13, 2002, nr 5, s. 1221-1239; L. A. Sicilianos, The Classification of Obligations and the Multilateral Dimension of the Relations of International Responsibility, ,European Journal of International Law” 13, 2002, nr 5, s. 1127; A. Kozłowski, B. Mielnik (red.), Odpowiedzialność międzynarodowa jako element miedzynarodowego porzadku prawnego, Wrocław 2009, s. 327.

${ }^{7}$ Generalnie uzasadniony wydaje się pogląd R. Ago, specjalnego sprawozdawcy KPM w dziedzinie odpowiedzialności prawnomiędzynarodowej, który twierdził, że odpowiedzialność obejmuje różne formy nowych stosunków prawnych, powstałych w następstwie naruszenia zobowiązania międzynarodowego państwa, zob. YBILC 1970, t. II, s. 179-184.

${ }^{8}$ MTS w opinii doradczej z 1996 r. na temat legalności używania przez państwo broni jądrowej w konfliktach zbrojnych (Legality of the Use by a State of Nuclear Weapons in Armed Conflicts) stwierdził, że: ,sam fakt, że większość państw głosując nad uchwałą, przestrzegała wszystkich istotnych przepisów formalnych, nie może wystarczyć, by zapobiec jakimkolwiek defektom fundamentalnym, tak jak działanie ultra vires, czym może być obarczona ta uchwała”; zob. ICJ, Reports 1996, § 29, s. 82.
} 
Po drugie - niezbędne jest przypisanie ${ }^{9}$ deliktu organizacji międzynarodowej ${ }^{10}$ (także wtedy gdy organizacja działa ultra vires) ${ }^{11}$. Na tym tle szczególnej wymowy nabiera podmiotowość prawnomiędzynarodowa, która oznacza zdolność do posiadania praw i obowiązków wynikających bezpośrednio z prawa międzynarodowego. Zasadą nadrzędna jest ipso facto poddanie odpowiedzialności deliktowej organizacji międzynarodowej prawu miejsca popełnienia deliktu. Jednakże reguła ta jest uchylona w sytuacji odpowiedzialności za naruszenia prawa $\mathrm{w}$ czasie operacji pokojowych $\mathrm{ONZ}^{12}$. Właściwym przykładem obrazującym tę sytuację jest przepis art. 288 ust. 2 Traktatu ustanawiającego Wspólnotę Europejską (TWE), który zakłada odpowiedzialność Wspólnoty Europejskiej za działania samej organizacji lub jej funkcjonariuszy na niekorzyść jednostek.

Po trzecie - warunkiem odpowiedzialności organizacji międzynarodowych jest naruszenie normy prawa międzynarodowego ${ }^{13}$, wiążącej daną organizację międzynarodową (wskazać tu możemy odpowiedzialność za naruszenia prawa regulującego działalność określonej organizacji, ale również odpowiedzialność za naruszenia norm powszechnego prawa międzynarodowego ${ }^{14}$. Bez wątpienia

${ }^{9}$ Istotnym zagadnieniem w świetle prawa dotyczącego odpowiedzialności prawnomiędzynarodowej organizacji jest określenie jej zakresu, tzn. ustalenie, czyje działanie lub zaniechanie $\mathrm{i}$ w jakich okolicznościach zostanie przypisane organizacji. Atrybucja wskazuje zatem, jakie zachowanie organizacji będzie uznane, zgodnie z prawem międzynarodowym, za akt tej organizacji, zob. YBILC 1973, t. II, s. 189. E. Lauterpacht dochodzi do słusznego, jak się wydaje, wniosku, że: ,Ściśle związane z pojęciem pozwolenia musi być pojęcie efektu upływu czasu. [...] Tam gdzie nie ma postanowień dotyczących efektu upływu czasu, może on wpływać na akty ultra vires na dwa sposoby. Po pierwsze, może powstrzymywać stronę poszkodowaną od skarg dotyczących nielegalności aktu nielegalnego. Po drugie, może on, jeżeli akt jest powtórzony, działać, rozszerzając uprawnienia organizacji, aby włączyć do nich akt, który był początkowo ultra vires"; zob. idem, The Legal Effects of Illegal Acta of International Organisations, w: Cambridge Essays in International Law. Essays in Honour of Lord McNair, London-Dobbs Ferry-New York 1965, s. 119.

${ }^{10} \mathrm{Na}$ marginesie rozważań należy zaznaczyć, że w prawie międzynarodowym nie opracowano teorii deliktu międzynarodowego, dzięki której możliwe byłoby uzupełnienie ogólnej koncepcji deliktu określeniem kryteriów wyróżniających poszczególne rodzaje deliktów, zob. na ten temat szerzej: J. Combacau, D. Alland, „Primary” and „Secondary” Rules in the Law of State Responsibility: Categorizing International Obligations, ,Netherlands Yearbook of International Law” 16, 1985, s. 82.

11, ,...] jedynym doniosłym przykładem międzynarodowego rozważania skutków nielegalnych aktów organizacji międzynarodowych jest przykład opinii doradczej MTS dotyczącej Certain expenses of the United Nations. [...] Stanowisko Francji pokrótce brzmiało, że ZO ONZ nie może nakładać zobowiązań finansowych w odniesieniu do działania podjętego jako ultra vires. Zezwolenie na modus operandi pewnie skutkowałoby wyposażeniem ZO ONZ w ogólne uprawnienia legislacyjne”, zob. E. Lauterpacht, op. cit., s. $106-107$.

12 Tak np. A. Reinish, International Organizations before National Courts, Cambridge 2000, s. 80-81. Z kolei L. Oppenheim uznawał wprawdzie odpowiedzialność państwa za akty ultra vires, ale na zasadzie odpowiedzialności za cudze czyny, a nie w oparciu o zasadę przypisania danego aktu państwu, zob. idem, International Law. A Treatise, wyd. 7, London-New York-Toronto 1948, s. 330-332. H. G. Schermers i N. M. Blokker twierdzą, że każda organizacja zawierająca porozumienie, które łamie własną konstytucję, dokonuje aktu ultra vires, zob. iidem, International Institutional Law, Boston-Leiden 2003, s. 560 .

${ }^{13}$ Por. International Law Commission, 2001 Draft Articles on Responsibility of States for Internationally Wrongful Acts Adopted by the Drafting Committee on Second Reading, UN Doc., /CN.4/L.620/Rev.1.

${ }^{14}$ Warto dodać, że B. Conforti wymienia dwie nadrzędne przesłanki ,nielegalności” aktów instytucjonalnych organizacji międzynarodowych: 1) naruszenie podstawowych przepisów, związanych z porządkiem prawnym organizacji międzynarodowej; 2) brak kompetencji organizacji do podjęcia 
wymienione tu warunki odpowiedzialności organizacji międzynarodowych przewiduje również stworzony przez KPM projekt prawnej regulacji odpowiedzialności organizacji międzynarodowych ${ }^{15}$. Faktem niepodważalnym jest, że zgodnie z rozwiązaniem przyjętym w projekcie (art. 3) każdy niezgodny z prawem międzynarodowym akt organizacji międzynarodowej prowadzi do odpowiedzialności międzynarodowej organizacji.

Konwencja dotycząca Światowej Organizacji Meteorologicznej (WMO) ${ }^{16}$ i konstytucja Światowej Organizacji Zdrowia (WHO) ${ }^{17}$ zawieraja regulujace postępowanie postanowienia, które mają na celu rozwiązanie sporów dotyczących interpretacji i stosowania obu tych aktów. W wypadku WMO możliwe wydaje się zastosowanie art. 29 konwencji (zamieszczonego w części XVI: „Interpretacja i spory”), natomiast w wypadku WHO - art. 75 lub ewentualnie art. 76 konstytucji (zamieszczonych w rozdziale XVIII: „Interpretacja”). W WMO procedura ta przedstawia się następująco. Zgodnie z treścią art. 29: ,_...] każda sprawa lub spór, dotyczące interpretacji lub stosowania Konwencji” powinny być $\mathrm{w}$ pierwszej kolejności rozstrzygnięte na drodze negocjacji pomiędzy państwami lub przez Kongres Meteorologiczny. Konwencja milczy w kwestii wyboru rozstrzygnięcia pomiędzy tymi dwoma sposobami. Wydaje się, że w razie nieważności uchwały bardziej prawdopodobne jest rozpatrzenie sprawy przez Kongres niż przez państwa na drodze negocjacji, ponieważ zarzut nieważności kierowany będzie raczej pod adresem samej organizacji, a nie w stosunku do innego państwa. Nie można jednak wykluczyć możliwości podniesienia zarzutu nieważności przez jedno z państw członkowskich i zakwestionowanie takiego stwierdzenia przez inne, a tym samym powstania między nimi sporu. Jeśli zaś sprawa nie zostanie rozwiązana ani w drodze negocjacji, ani przez Kongres, trzeba ja przekazać niezawisłemu arbitrowi wyznaczonemu przez przewodniczącego MTS. Odstępstwo od powyższej procedury jest możliwe tylko wtedy, gdy strony wspólnie dojdą do kompromisu w kwestii sposobu załatwienia sprawy.

Procedura przewidziana na podstawie art. 75 konstytucji WHO także w pierwszej fazie zakłada rozstrzygnięcie określonego zagadnienia na drodze negocjacji albo przez właściwy organ, którym w tej sytuacji jest Zgromadzenie Zdrowia. Kwestie nierozstrzygnięte $\mathrm{w}$ powyższy sposób przekazywane są do MTS, na podstawie postanowień jego statutu. Ponadto art. 76 konstytucji zakłada, że WHO - dzięki upoważnieniu udzielonemu przez ONZ - ma prawo wystąić do MTS o udzielenie opinii prawnej ,we wszelkich kwestiach prawnych powstałych w zakresie kompetencji Organizacji”. Trzeba zauważyć, że także ten przepis może mieć zastosowanie w razie pojawienia się wątpliwości

uchwały, idem, The Law and Practice of the United Nations, Hague-London-Boston 2000, s. 293. Por. K. Skubiszewski, Uchwały prawotwórcze organizacji międzynarodowych. Przeglad zagadnień $i$ analiza wstepna, Poznań 1965, s. 113.

${ }_{15}$ Zob. United Nations International Law Commission - Report on the Work of Its Sixtieth Session, http://untreaty.un.org/ilc/reports/2008/2008report.htm (20.04.2010).

${ }^{16}$ Aktem konstytuującym WMO jest Konwencja WMO podpisana 11 października $1947 \mathrm{r}$. w Waszyngtonie, zob. Dz. U. 1951, Nr 11, poz. 85, załącznik, z późn. zm.

${ }^{17}$ Instytucjonalne podstawy funkcjonowania WHO tworzy podpisana 22 lipca 1946 r. w Nowym Jorku Konstytucja WHO, zob. Dz. U. 1948, Nr 61, poz. 477 z późn. zm. 
co do nieważności uchwały Zgromadzenia, kiedy to organizacja sama może wystąpić z pytaniem, czy podjęta przez nią uchwała jest ważna.

Istotne wydają się postanowienia określone w art. 84 i 85 Konwencji chicagowskiej (rozdział XVIII: „Spory i uchybienia”) ${ }^{18}$, jednakże i one dotycza wszelkich sporów, a także aspektów związanych $\mathrm{z}$ postępowaniem $\mathrm{w}$ razie nieważności. Artykuł 84 zakłada, że każde ,nieporozumienie” ${ }^{19}$ między członkami organizacji, związane $\mathrm{z}$ wykładnią lub zastosowaniem konwencji i jej załączników (a więc uchwał prawotwórczych), powinno być rozstrzygnięte w drodze rokowań. Jeżeli jest to niemożliwe, nieporozumienie (na wniosek jakiegokolwiek państwa, którego ono dotyczy) może zostać rozstrzygnięte przez Radę Organizacji Międzynarodowego Lotnictwa Cywilnego. Członek Rady, który jest jednocześnie stroną w sporze, nie posiada prawa głosu w tej sprawie. Trzeba bowiem pamiętać, że od uchwały Rady przysługuje odwołanie do powołanego ad hoc sądu polubownego lub do MTS (o fakcie złożenia odwołania należy poinformować Radę Organizacji Międzynarodowego Lotnictwa Cywilnego w terminie sześćdziesięciu dni od otrzymania zawiadomienia o decyzji). Artykuł 85 określa w sposób szczegółowy zasady powoływania sądu polubownego (każde z państw wskazuje swego arbitra, oni zaś wyznaczają superarbitra).

Procedura wskazana w art. 84 została już w praktyce zastosowana w sprawie Appeal Relating to the Jurisdiction of the ICAO Council ${ }^{20}$ rozpatrywanej przez MTS.

W interesującym nas kontekście należy podkreślić, że Międzynarodowy Trybunał Sprawiedliwości w swojej opinii doradczej w sprawie IMCO Case ${ }^{21}$, której domagała się Międzyrządowa Morska Organizacja Doradcza (IMCO), postanowił, że modus operandi przyjęty przez organizację (to znaczy jej Zgromadzenie) w wyborze Komitetu Bezpieczeństwa Morskiego (Maritime Safety Committee) był ultra vires, ponieważ organizacja błędnie zinterpretowała termin ,największe kraje posiadające statki” (,largest ship-owning nations”).

${ }^{18}$ ICAO została utworzona na mocy Konwencji ICAO podpisanej 7 grudnia 1944 r. w Chicago (tzw. Konwencja chicagowska). Należy podkreślić, że druga część Konwencji chicagowskiej jest statutem ICAO. Uzupełnieniem Konwencji chicagowskiej są dwa układy dotyczące regularnych służb powietrznych, tj. układ o tranzycie międzynarodowych służb powietrznych oraz układ o międzynarodowym transporcie lotniczym, zob. Dz. U. 1959, Nr 35, poz. 212 z późn. zm.

19 Takiego określenia użyto w Konwencji chicagowskiej.

${ }^{20}$ Appeal Relating to the Jurisdiction of the ICAO Council, ICJ, Reports 1972, s. 46.

${ }^{21}$ ICJ Reports 1960, s. 150. Decyzja podjęta przez Zgromadzenie w wyniku tej opinii, która nie wykazywała, jakie są konsekwencje aktu ultra vires, była następująca: 1) komitet, który został wybrany 1959 r. powinien zostać rozwiązany; 2) nowy komitet powinien zostać ukonstytuowany zgodnie z interpretacja konstytucji IMCO przez MTS; 3) kroki podjęte przez Komitet w okresie 1959-1961 zostały przyjęte i potwierdzone, zob. C. F. Amerasinghe, Principles of the Institutional Law of International Organization, Cambridge 2005, s. 177-178. Jak konstatuje C. F. Amerasinghe: „Po pierwsze sa pewne niezgodności w działaniu podjętym przez zgromadzenie IMCO, ale rozwiązanie musi być uznane za pragmatyczne i bardziej zgodne $\mathrm{z}$ rozumieniem, że konsekwencją niewłaściwego wykorzystania uprawnienia jest nieważność oryginalnego aktu, który uczynił go nieważnym, nie zaś możliwym do unieważnienia. Po drugie rzeczą zachęcającą jest, że opinie MTS przyjęto i przestrzegano jej. Po trzecie w sposób, w jaki wyrażono prośbę o orzeczenie, i wynikająca z niego opinia nie pozostawiły organizacji innej alternatywy niż przyjęcie opinii sformułowania swego rodzaju planu działania jako rozwiązania”, (ibidem, s. 178, tłum. M.R.). 
W tej opinii doradczej MTS po raz pierwszy utrzymywał, że wykonanie uprawnienia przez organizację było ultra vires ${ }^{22}$.

Z kolei w sprawie Gabcikovo-Nagyramos ${ }^{23}$ (Węgry/Słowacja) w 1997 r. Międzynarodowy Trybunał Sprawiedliwości stwierdził, że ocena, czy traktat pozostaje $\mathrm{w}$ mocy lub czy został $\mathrm{w}$ należyty sposób wypowiedziany albo zawieszony, dokonywana jest na podstawie norm obowiązujących na gruncie prawa traktatów. Natomiast ustalenie, w jakim zakresie zawieszenie, wypowiedzenie traktatu jest niezgodne $\mathrm{z}$ prawem traktatów, należy do zakresu prawa o odpowiedzialności państw.

N. Buchowska wymienia trzy przesłanki nieważności uchwał organizacji międzynarodowych. Po pierwsze, autorka uważa, że nieważny akt prawny można określić (stosowanym w literaturze brytyjskiej) mianem „niebyłego”. Jest to akt dotknięty wadą polegającą na braku istotnego wymogu decydującego o jego ważności. Po drugie, zaznacza, że akt prawny może być dotknięty nieważnością absolutną (bezwzględną). Zdaniem N. Buchowskiej, trzecim rodzajem nieważności jest tak zwana nieważność względna. W tym wypadku akt prawny nie jest nieważny $a b$ initio, a nieważność nie występuje automatycznie. Niemniej akt prawny dotknięty nieważnością względną może być anulowany przez sąd lub inny kompetentny organ, przy czym orzeczenie takiego organu będzie miało charakter konstytutywny ${ }^{24}$. Tak więc można $\mathrm{z}$ dużą dozą prawdopodobieństwa przyjąć, że nieważność jest stwierdzana ze skutkiem ex tunc. Natomiast aktem sprzecznym z prawem międzynarodowym jest akt, który można odnieść do organizacji zgodnie $\mathrm{z}$ prawem międzynarodowym i który stanowi naruszenie międzynarodowego zobowiązania tej organizacji. J. Klabbers wymienia następujące przyczyny nieważności aktu instytucjonalnego organizacji międzynarodowej: ,1) nieważność aktu instytucjonalnego od samego początku, a więc niemożność uznania go za prawnie skuteczny (na przykład traktat zawarto pod przymusem lub też z naruszeniem norm prawa międzynarodowego); 2) nieważność aktu instytucjonalnego nie posiada mocy wstecznej (to znaczy nieważny akt instytucjonalny może prawnie obowiązywać od wejścia w życie do momentu udowodnienia nieważności); 3) nieważność częściowa (błąd dotyczy jedynie części dokumentu organizacji)" ${ }^{25}$.

W moim przekonaniu, na podkreślenie zasługuje fakt, że przedłożony przez KPM projekt ${ }^{26}$ zakłada także przesłanki wyłączające bezprawność aktów organizacji międzynarodowych. Należą do nich między innymi: zgoda drugiej strony (państwa bądź innej organizacji międzynarodowej - art. 17), samoobrona (art. 18) czy też force majeure (art. 20). Bezsprzecznie bowiem jest to o tyle

${ }^{22}$ Por. the Competence of the ILO to Regulate Agricultural Production Case, PCIJ, Series B, nr 3.

${ }^{23}$ Zob. ICJ, Reports 1997, pkt 47, s. 38.

${ }^{24}$ Zob. N. Buchowska, Problematyka nieważności uchwat prawotwórczych organizacji międzynarodowych, w: P. Wiliński, O. Krajniak, B. Guzik (red.), Prawo wobec wyzwań wspótczesności, t. III, Poznań 2006, s. 206-207.

${ }^{25}$ Szerzej na ten temat: J. Klabbers, An Introduction to International Institutional Law, Cambridge 2002, s. 239-240.

${ }^{26}$ Zob. United Nations International Law Commission - Report on the Work of Its Sixtieth Session, http://untreaty.un.org/ilc/reports/2008/2008report.htm (20.04.2010). 
istotne, że warunkiem odpowiedzialności organizacji międzynarodowych są ich akty bezprawne (art. 3). Jednocześnie dopuszczono możliwość przypisania organizacji bezprawnego aktu ultra vires jako podstawy jej odpowiedzialności prawnomiędzynarodowej (art. 6). Uważam, iż wskazane okoliczności wyłączające bezprawność odnoszą się również do aktów ultra vires organizacji (jej organu). W konsekwencji można przyjąć, że odpowiedzialność międzynarodowa organizacji międzynarodowej za akty ultra vires będzie mogła zostać wyłączona między innymi w razie działania za zgodą drugiej strony czy też pod wpływem siły wyższej.

\section{PRZYKŁADY PRZEKROCZENIA KOMPETENCJI PRZEZ ORGANIZACJE MIEDZYNARODOWE}

Niekiedy trudności w dokładnym określeniu kompetencji organów organizacji międzynarodowej stwarzaja niebezpieczeństwo przekroczenia przez organ jego kompetencji (działanie ultra vires). Właściwym przykładem tej sytuacji są sprawy wiążące się z działalnością organów $\mathrm{ONZ}^{27}$, które omówię poniżej.

Pierwsza z nich wynikła w związku z utworzeniem UNEF (Doraźnych Sił ONZ) rozmieszczonych w Egipcie w $1956 \mathrm{r}$. Warto dodać, że powołała je nie Rada Bezpieczeństwa ONZ (RB ONZ), ale Zgromadzenie Ogólne ONZ (ZO ONZ) na mocy rezolucji Uniting for Peace z 23 listopada $1950 \mathrm{r} .{ }^{28} \mathrm{~W}$ rezolucji tej postanowiono, że we wszystkich wypadkach, które zdają się stanowić zagrożenie pokoju, złamanie pokoju lub akt agresji, a RB ONZ z powodu braku jednomyślności stałych członków przestaje ponosić odpowiedzialność za utrzymanie międzynarodowego pokoju i bezpieczeństwa, ZO ONZ powinno zając się de facto sprawą niezwłocznie, celem skierowania odpowiednich zaleceń do swych członków odnośnie do środków zbiorowych, wliczając $\mathrm{w}$ to, w przypadku złamania pokoju lub aktu agresji, użycie sił zbrojnych, jeżeli

${ }^{27}$ We wzajemnych stosunkach między Zgromadzeniem Ogólnym a Radą Bezpieczeństwa ONZ jest to tym bardziej widoczne, że art. 11 ust. 2 Karty ONZ upoważnia Zgromadzenie do zajmowania się kwestiami związanymi z utrzymaniem międzynarodowego pokoju i bezpieczeństwa. Jednocześnie wskazane zagadnienia stanowią główne pole zainteresowań Rady Bezpieczeństwa jako organu o ograniczonym składzie. Zgodnie z art. 39 Karty ONZ do RB należy stwierdzenie istnienia zagrożenia pokoju, naruszenia pokoju bądź aktu agresji. Jest ona bowiem organem, na którym spoczywa odpowiedzialność za utrzymanie międzynarodowego pokoju i bezpieczeństwa (art. 24 Karty ONZ). W rozumieniu Karty ONZ najbardziej powszechnym przypadkiem ,,zagrożenia dla pokoju” jest zagrożenie konfliktem zbrojnym między państwami, który może prowadzić do naruszenia pokoju lub aktu agresji. Pojęcie „,naruszenia pokoju” oznacza jakiekolwiek użycie siły zbrojnej, zob. M. S. Majlessi, Economic Sanctions in the United Nations Security System: Recent Developments, w: L. P. Forlati, L. A. Sicilianos, Economic Sanctions in International Law, Boston 2004, s. 530. Termin „,agresja” oznacza „użycie siły zbrojnej przez jedno państwo przeciwko suwerenności, integralności terytorialnej lub politycznej niezależności innego państwa, lub w jakikolwiek inny sposób niezgodny z Kartą Narodów Zjednoczonych”. Definicja ta została zaproponowana przez ZO ONZ w rezolucji nr 3314 (XXIX) z 1974 r., zob. UN GA Res. 3314/29 - Annex, 14 grudnia $1974 \mathrm{r}$.

${ }_{28}$ A/RES/5/377, zob. także: http://untreaty.un.org (20.04.2010). Zob. interesujące z tego punktu widzenia opracowanie: I. Petculescu, The Review of the United Nations Security Council Decisions by the International Court of Justice, „Netherlands International Law Review” 52, 2005, s. 183. 
będzie to niezbędne do utrzymania lub przywrócenia międzynarodowego pokoju i bezpieczeństwa. Warto zwrócić uwagę na polityczny aspekt sytuacji - bierność RB ONZ w tamtym czasie wynikała $z$ częstego wykorzystywania prawa weta przez Związek Radziecki. W związku z tym państwa członkowskie systemu ONZ próbowały ,przesunąć” ciężar odpowiedzialności na ZO ONZ, w którym miały większość.

Rezolucja Uniting for Peace zasługuje na uwagę $\mathrm{z}$ dwóch powodów. Po pierwsze, rezolucja ta jest wyrazem tych tendencji i dlatego wywołała sprzeciw Związku Radzieckiego. Po drugie, podnoszono, że jest niezgodna z postanowieniami Karty ONZ, które - zdaniem ZSRR - uprawnienia do stosowania środków przymusu rezerwują dla $\mathrm{RB} \mathrm{ONZ}^{29}$. Warto jednak od razu zaznaczyć, że wątpliwości w odniesieniu do rezolucji Uniting for Peace wskazuja, jak żyznym polem badawczym jest kwalifikacja aktów organów organizacji międzynarodowej jako aktów mieszczących się w ramach ich kompetencji ${ }^{30}$. W związku $\mathrm{z}$ tym potwierdzają też tezę o widocznym niebezpieczeństwie przekroczenia własnych kompetencji i tym samym działania ultra vires. Stwierdzono, że niewywiązywanie się przez RB ONZ z obowiązków powierzonych jej przez państwa członkowskie nie pozbawia ZO ONZ przysługujących mu praw ani nie zwalnia Zgromadzenia z ciążącej na nim na mocy Karty ONZ odpowiedzialności za utrzymanie światowego pokoju i bezpieczeństwa. Uważam, że nie sposób nie uznać dążeń ZO ONZ, które zmierzały do zapewnienia ONZ skutecznej realizacji jej celów: nie bez racji wobec braku aktywności RB ONZ wzięło ono na siebie odpowiedzialność za utrzymanie światowego pokoju i bezpieczeństwa. Rezolucja Uniting for Peace zakładała bowiem, że jeżeli RB ONZ nie będzie posiadała zdolności do podjęcia działań z powodu braku jednomyślności jej stałych członków, ZO ONZ w sytuacji stanu zagrożenia pokoju, jego naruszenia lub agresji może podjąć zalecenia służące zapewnieniu pokoju i bezpieczeństwa $^{31}$. Tak więc można z dużą dozą prawdopodobieństwa przyjąć, że wyłączność kompetencji RB ONZ w tym obszarze powoduje, że zastosowanie tego rodzaju środków prawnych będzie niezgodne z Kartą ONZ.

Trzeba zaznaczyć, że problem działania ultra vires organu ONZ powstał w odniesieniu do zagadnienia ustanowienia trybunałów międzynarodowych powołanych przez RB ONZ celem ścigania i karania jednostek za zbrodnie popełnione na terytorium byłej Jugosławii oraz w Ruandzie. Międzynarodowy Trybunał Karny dla byłej Jugosławii (MTKJ) ${ }^{32}$ został utworzony na mocy rezolucji RB ONZ. Należy podkreślić, że w rezolucji $\mathrm{nr} 808^{33}$ jako przesłanki powołania trybunału wskazano stałe dokonywanie zbrodni oraz naruszanie

${ }^{29}$ H. G. Schermers, N. M. Blokker, op. cit., s. 154.

${ }^{30}$ E. Osieke, The Legal Validity of Ultra Vires Decisions of International Organisations, „American Journal of International Law" 77, 1983, s. 239-256.

${ }^{31} \mathrm{~W}$. Bowett, The Impact of Security Council Decisions on Dispute Settlement Procedures, „European Journal of International Law” 5, 1994, nr 1, s. 89-101.

${ }^{32}$ Zob. A. Przyborowska-Klimczak, Sadownictwo międzynarodowe u progu XXI w., w: Państwo. Prawo. Myśl prawnicza. Prace dedykowane Grzegorzowi Leopoldowi Seidlerowi w dziewięćdziesiata rocznice urodzin, Lublin 2003, s. 212-214.

${ }^{33}$ S/RES/808 February 22, 1993, http://www.nato.int/Ifor/un/u930222a.htm (20.04.2010). Por. Report of the Secretary-General Pursuant to Paragraph 2 of Security Council Resolution 808 (1993), Doc S/25704, 3 May 1993, § 20. Raport ten zawiera uzasadnienie podstaw prawnych utworzenia Trybunału. 
międzynarodowego prawa humanitarnego na terytorium byłej Jugosławii, zobowiązując tym samym Sekretarza Generalnego ONZ do przedstawienia raportu oraz propozycji w tej sprawie. Następnie, na mocy rezolucji $\mathrm{nr} 827^{34}$, formalnie ustanowiono międzynarodowy trybunał, którego nadrzędnym celem było ściganie osób odpowiedzialnych za poważne naruszenia międzynarodowego prawa humanitarnego na terytorium byłej Jugosławii.

Warto dodać, że RB ONZ, ustanawiając Trybunał, odwołała się do swych kompetencji wynikajacych z art. 29 oraz z rozdziału VII Karty ONZ. Ten sposób utworzenia Trybunału został zakwestionowany w jednej ze spraw, które zostały $\mathrm{mu}$ przedstawione. Otóż obrońcy jednego z oskarżonych (Duško Tadića) ${ }^{35}$ podnieśli, że Międzynarodowy Trybunał Karny dla byłej Jugosławii został utworzony niezgodnie z prawem. Zarzut opierał się na twierdzeniu, iż RB ONZ, ustanawiając Trybunał na podstawie własnej rezolucji, działała ultra vires, gdyż żaden z przepisów Karty ONZ nie upoważnia jej do tworzenia organów sądowniczych. Sprawa stała się przedmiotem obrad Izby Apelacyjnej Międzynarodowego Trybunału Karnego dla byłej Jugosławii (Appeals Chamber of the International Criminal Tribunal for the former-Yugoslavia). Izba ta stwierdziła, że wyliczenie zawarte w art. 41 Karty ONZ nie jest pełne. Izba Apelacyjna Międzynarodowego Trybunału Karnego dla byłej Jugosławii utworzona do określenia legalności uchwały RB ONZ powołującej Trybunał orzekła, że szeroki zakres uznania nadany RB ONZ na podstawie art. 39 Karty ONZ nie oznaczał, iż jego uprawnienia były zupełne: „Rada Bezpieczeństwa podlega pewnym ograniczeniom konstytucyjnym niezależnie od tego, jak szerokie są jej uprawnienia zgodne z Konstytucją. Przede wszystkim należy zauważyć, iż uprawnienia te $\mathrm{w}$ żaden sposób nie moga przekroczyć granic ogólnej jurysdykcji organizacji, nie mówiąc już o innych konkretnych ograniczeniach lub tych, które moga pochodzić z podziału władzy w ramach organizacji. Ani tekst, ani duch Karty nie uznaje Rady Bezpieczeństwa za legibus solutus (niezwiązaną prawem)" ${ }^{36}$. Ostatecznie uznano dyskrecjonalny charakter uprawnienia RB ONZ, wynikającego z art. 41 Karty ONZ, a co z tym - możliwość podejmowania różnego rodzaju działań, które zgodnie $\mathrm{z}$ art. 39 Karty ONZ mają na celu utrzymanie lub też przywrócenie międzynarodowego pokoju i bezpieczeństwa. Tak więc można z dużą dozą prawdopodobieństwa przyjąć, że powołanie Trybunału na podstawie rezolucji RB ONZ nie ma charakteru aktu ultra vires, ponieważ Rada stosuje taki środek przywrócenia pokoju i bezpieczeństwa, jaki uzna za właściwy. Innymi słowy, RB ONZ utworzyła organ o charakterze sadowniczym jako narzędzie służące przywracaniu pokoju w byłej Jugosławii, co niewątpliwie służy utrzymaniu światowego pokoju i bezpieczeństwa ${ }^{37}$.

\footnotetext{
${ }^{34}$ Pełna nazwa „Międzynarodowy Trybunał Karny dla osądzania osób odpowiedzialnych za poważne naruszenia międzynarodowego prawa humanitarnego na terytorium byłej Jugosławii między 1 stycznia 1991 r. a datą, która zostanie określona przez Radę Bezpieczeństwa po przywróceniu pokoju”, zob. S/RES/827 May 25, 1993.

35 Sprawa IT-94-1, „Prijedor”.

${ }^{36}$ Zob. case IT-94-1-AR 72, 105 I.L.R. 465, § 28 (tłum. M.R.).

${ }^{37} \mathrm{~W}$ doktrynie istnieje jednak pogląd, że rozszerzająca interpretacja Karty ONZ, zgodnie z którą RB ONZ może podejmować środki niewymienione wprost w rozdziale VII Karty ONZ, nawet jeżeli służą one
} 
Istnieją także pewne wątpliwości co do legalności utworzenia Międzynarodowego Trybunału Karnego dla Ruandy (MTKR) ${ }^{38}$. Uzasadnienie powołania tego Trybunału oraz podstawy prawne jego ustanowienia odzwierciedlaja przypadek Międzynarodowego Trybunału Karnego dla byłej Jugosławii, co było przedmiotem wcześniejszej analizy.

\section{ZAGADNIENIE INTERWENCJI HUMANITARNEJ W KONTEKŚCIE ODPOWIEDZIALNOŚCI ORGANIZACJI MIEDDZYNARODOWYCH}

Współcześnie prima facie problematyka dopuszczalności interwencji humanitarnej jest kwestią sporną z zakresu prawa międzynarodowego publicznego. Dotyczy ona bowiem stykania się dwóch fundamentalnych zasad: tradycyjnej zasady poszanowania suwerenności państwowej i zasady ochrony praw człowieka ukształtowanej w drugiej połowie XX w. Trafną definicję ,,interwencji humanitarnej” podaje A. Mężykowska: ,,...] możliwość przeprowadzenia akcji wojskowej przy użyciu siły zbrojnej w przypadkach drastycznych naruszeń praw człowieka” ${ }^{39}$. A. Domagała twierdzi, że: „Interwencja sensu largo jest każdy rodzaj wpływu na suwerenne państwo i jego sprawy wewnętrzne" ${ }^{40}$. Autor ten dodaje także, że: „Interwencją sensu stricto jest celowe działanie państwa wymierzone $\mathrm{w}$ zmianę struktury politycznej w innym państwie wbrew jego woli z użyciem środków militarnych" ${ }^{41}$. Doktryna interwencji humanitarnej opiera się na założeniu, że państwo ma obowiązek zagwarantowania swoim obywatelom pewnych praw, niezbędnych do egzystencji społeczeństwa i utrzymania pokoju międzynarodowego. Naruszenie tych praw upoważniać ma inne państwa do interwencji ${ }^{42}$. Warto dodać, że przeciwnicy uznania interwencji humanitarnej za legalną przywołują fakt, iż zasady użycia siły określone w Karcie ONZ i innych dokumentach prawa międzynarodowego nie dotycza prawa do interwencji zbrojnej $\mathrm{w}$ obronie praw ludności obcego państwa. Podkreślają oni ponadto, że z zasady poszanowania suwerenności państwowej

\footnotetext{
przywróceniu pokoju, jest niezgodna $\mathrm{z}$ tradycyjnym rozumieniem prawa międzynarodowego, przyznającym organom międzynarodowym możliwość działania tylko na podstawie wyraźnego upoważnienia udzielonego przez państwa-strony umowy powołującej ten organ, zob. J. E. Alvarez, Nuremberg Revisited: The Tadić Case, ,European Journal of International Law” 7, 1996, nr 2, s. 245.

${ }^{38}$ Pełna nazwa: „Międzynarodowy Trybunał Karny dla osądzania osób odpowiedzialnych za ludobójstwo i inne poważne naruszenia międzynarodowego prawa humanitarnego popełnione na terytorium Ruandy oraz obywateli Ruandy odpowiedzialnych za ludobójstwo i inne takie poważne naruszenia popełnione na terytorium sąsiadujących państw między 1 stycznia a 31 grudnia 1994 r.”, zob. S/RES/955, 1994.

${ }^{39}$ Zob. A. Mężykowska, Interwencja humanitarna $w$ świetle prawa międzynarodowego, Warszawa 2008, s. 22.

${ }^{40}$ Zob. A. Domagała, Interwencja humanitarna $w$ stosunkach międzynarodowych, Bydgoszcz-Wrocław 2008, s. 16.

${ }^{41}$ Ibidem, s. 18.

${ }^{42}$ Zob. A. Rougier, La théorie de l'intervention d'humanité, „Revue générale de droit international public" 17, 1910, s. 468 .
} 
wynika de facto zakaz ingerencji w sprawy wewnętrzne. A. Cassese wskazał sześć warunków, których spełnienie umożliwi przeprowadzenie interwencji humanitarnej nawet w sytuacji braku zgody RB ONZ, a więc między innymi przypadek naruszenia praw człowieka na skalę globalną, który doprowadziłby do śmierci setek, a nawet tysięcy niewinnych ludzi, a także gdyby doszło do zbrodni przeciw ludzkości na terytorium suwerennego państwa, dokonywanych przez władze albo za ich zgodą lub w sytuacji upadku władzy w określonym państwie ${ }^{43}$. J. Zajadło także wskazuje kryteria dopuszczalności interwencji humanitarnej, do których zalicza: uprawniony autorytet, ostateczność rozwiązania, pozytywną prognozę, słuszne intencje, proporcjonalność środków ${ }^{44}$.

Warto dodać, że tradycyjne stanowisko prawa międzynarodowego w kwestii jednostronnej interwencji w wewnętrzne konflikty zbrojne zostało wypracowane w wyroku MTS, który dotyczy działalności militarnej i paramilitarnej w Nikaragui ${ }^{45}$. Należy przypomnieć, że art. 2 ust. 7 Karty ONZ ${ }^{46}$, będący potwierdzeniem zasady nieingerencji w sprawy wewnętrzne państw, nie jest związany z sytuacjami, w których RB ONZ podejmuje decyzję o zastosowaniu środków przymusu przewidzianych w rozdziale VII Karty ONZ. Trzeba uwzględnić fakt, że gdy RB ONZ stwierdzi, iż sytuacja w określonym państwie stanowi zagrożenie dla międzynarodowego pokoju i bezpieczeństwa, konieczne jest podjęcie akcji zbiorowej celem jego przywrócenia.

Kluczowe w tej kwestii wydaje się pytanie, czy sytuację wewnętrzną można traktować jako zagrożenie międzynarodowego pokoju i bezpieczeństwa. Praktyka RB ONZ w tym względzie udziela odpowiedzi twierdzącej. Otóż w $1992 \mathrm{r}$. RB ONZ w rezolucji $\mathrm{nr} 788^{47}$ udzieliła przyzwolenia na działania interwencyjne sił regionalnych Ekonomicznej Organizacji Państw Zachodniej

${ }^{43}$ Zob. A. Cassese, Ex iniuria ius oritur: Are We Moving towards International Legitimation of Forcible Humanitarian Countermeasures in the World Community?, ,European Journal of International Law" 10, 1999, s. 27-30.

${ }^{44}$ Zob. J. Zajadło, Stuszna przyczyna jako przestanka legitymizacyjna interwencji humanitarnej. Studium z filozofii prawa międzynarodowego, „Kwartalnik Prawa Publicznego” 2005, nr 1-2, s. 53-54.

${ }^{45}$ Zob. ICJ, Reports 1986, nr 14, s. 120-126. Mianowicie tylko w przypadku, gdy rząd państwa zwraca się z prośbą o dokonanie interwencji, inne państwa mogą odpowiedzieć pozytywnie na to wezwanie.

${ }^{46}$ Prawo międzynarodowe zakazuje groźby lub użycia siły w stosunkach międzynarodowych (art. 2 ust. 4 Karty ONZ). Interwencja humanitarna może także być uznana za niedopuszczalna z powodu niezgodności z art. 2 ust. 7 Karty ONZ, zakazującym ingerencji w sprawy wewnętrzne państw. Uznanie suwerenności - niepodległości oraz wolności państw od ingerencji i wpływów zewnętrznych dotyczących ich polityki krajowej i zagranicznej oraz prawnej równości państw wyklucza w zasadzie możność ingerencji przez państwa trzecie. Jedyny wyjątek stanowić może pomoc dla państwa, na które dokonano napaści zbrojnej (samoobrona kolektywna). Wydaje się, że analogicznie można traktować prośbę o interwencję skierowaną przez rząd de iure, który został pozbawiony władzy w sposób niekonstytucyjny. Wyjątki od art. 2 ust. 4 są wyraźnie określone w Karcie ONZ i zawieraja jedynie działanie w obronie własnej (zgodnie z art. 51 Karty ONZ) oraz działanie militarne autoryzowane przez RB ONZ (zgodnie z art. 42 lub 53 Karty ONZ). Od końca lat 80. ubiegłego wieku ONZ odegrała decydująca rolę w wypracowaniu porozumień kończących konflikty wewnętrzne w takich państwach, jak: Kambodża (Akt Końcowy Konferencji Paryskiej dot. Kambodży z 1991 r., dok. NZ A/46/608, S/RES/745, 1992); Namibia (Porozumienie Trójstronne w sprawie Afryki Południowozachodniej z 1989 r., International Legal Materials 28, s. 944, S/RES/629, 1989); Liberia (dok. NZ S/26272, 1993, S/RES/813, 1993); Angola (S/RES/696, 1991); Timor (S/RES/1264, 1999).

${ }^{47} \mathrm{~S} / \mathrm{RES} / 788,1992$. 
Afryki (Economic Community of West African States - ECOWAS) w wojnie domowej $\mathrm{w}$ Liberii. Podjęła ona interwencję $\mathrm{w}$ celu powstrzymania wojny cywilnej i odbudowy państwa będącego w stanie upadku. Trzeba zaznaczyć, że od $1991 \mathrm{r}$. miały miejsce interwencje w Iraku ${ }^{48}$ podejmowane przez Stany Zjednoczone, Wielką Brytanię i Francję. Rada w rezolucji nr 688 (1991 r. $)^{49}$, uznała sytuację w Iraku za zagrożenie dla międzynarodowego pokoju i bezpieczeństwa. Z kolei Stany Zjednoczone ustanowiły strefy bez przelotów (no fly zones) nad południowym Irakiem dla bezpieczeństwa niesienia pomocy humanitarnej. Ipso facto wydaje się, że można traktować wydanie rezolucji nr 688 przez RB ONZ jako zgodę na interwencję, ale nie była to zgoda wypowiedziana bezpośrednio ${ }^{50}$. Nie bez racji RB ONZ udzieliła zezwolenia na użycie siły i ingerencję w sytuacji konfliktów w Somalii ${ }^{51}$ i Ruandzie ${ }^{52}$.

Rezolucja $\mathrm{nr} 1199 \mathrm{RB}$ ONZ $^{53}$ zasługuje na uwagę $\mathrm{z}$ dwóch powodów. Po pierwsze, w rezolucji tej RB ONZ oceniła konflikt w Kosowie jako „zagrożenie dla pokoju i bezpieczeństwa w regionie” oraz zażądała podjęcia natychmiastowych kroków celem „odwrócenia katastrofy humanitarnej”. Po drugie, Niezależna Międzynarodowa Komisja uznała interwencję przeprowadzona $\mathrm{w}$ Kosowie za niezgodną $\mathrm{z}$ prawem, ponieważ nie wydano rezolucji RB ONZ, lecz była legitymizowana, gdyż doprowadziła do rozwiązania kryzysu humanitarnego, a także uzyskała poparcie członków społeczności międzynarodowej. Komisja zaznaczyła również, że luka między legalnością a legitymizacją jest groźna i powinna być zlikwidowana przez określenie warunków dopuszczalności ${ }^{54}$.

Należy podkreślić, że prawo do interwencji humanitarnej ma per se charakter szczególny, uzasadniany z reguły wyjątkowymi okolicznościami natury humanitarnej. Dokonana analiza poparta przykładami z praktyki RB ONZ nie przemawia za dopuszczalnością interwencji humanitarnej na obecnym etapie rozwoju prawa międzynarodowego. Notabene nieprzychylność większości państw wobec legalizacji zbrojnych akcji humanitarnych z reguły wynika z obojętności na masowe naruszenia praw człowieka. Wyjątków od zakazu użycia siły zbrojnej nie można interpretować, stosując wykładnię rozszerzającą. Niewłaściwe wydaje się także twierdzenie dotyczące zmiany Karty ONZ na

\footnotetext{
48 J. Symonides, Narody Zjednoczone wobec wyzwań $i$ zagrożeń XXI w. Między koniecznościa a możliwościa reformy, ,Stosunki Międzynarodowe” 30, 2004, nr 3-4, s. 21.

49 S/RES/0688, 1991.

${ }^{50}$ W. Czapliński, Interwencja $w$ Iraku z punktu widzenia prawa międzynarodowego, „Państwo i Prawo" 2004, z. 1, s. 18-34.

${ }^{51} \mathrm{~S} / \mathrm{RES} / 794,1992$. W następstwie gwałtownych walk między oddziałami rządowymi a grupami rebeliantów, do których doszło w styczniu 1991 r., obalono i wygnano somalijskiego prezydenta M. Siad Barre’a, w wyniku czego Somalia pogrążyła się w wojnie domowej. Rywalizacja klanów doprowadziła do ogłoszenia w maju 1991 r. secesji północnej Somalii, zob. na ten temat J. Ryszka, Sankcje gospodarcze wobec podmiotów zewnętrznych w prawie i praktyce Unii Europejskiej, Toruń 2008, s. 94.

52 S/RES/929, 1994. Zacięte walki pomiędzy plemionami Tutsi i Hutu, które toczyły się od 1990 r., doprowadziły do zbrodni ludobójstwa.

53 S/RES/1199, 1998.

${ }^{54}$ Humanitarian Intervention: A Forum, ,The Nation”, http://www.thenation.com/doc/20030714/ forum (20.04.2010).
} 
drodze analogii do normy zwyczajowej dopuszczającej interwencję humanitarna, ponieważ brak w tym zakresie powszechnej opinio iuris państw. Warto jednak od razu zaznaczyć, że świadczy też o tym sprzeciw wielu państw wobec legalności tego typu akcji, które często nie są zgodne $\mathrm{z}$ ich interesami politycznymi ${ }^{55}$.

\section{WNIOSKI}

Przegląd zagadnień dotyczących odpowiedzialności organizacji międzynarodowych za akty ultra vires pozwala na sformułowanie następujących wniosków. Wynikaja one expressis verbis $\mathrm{z}$ rozważań powstałych $\mathrm{w}$ związku $\mathrm{z}$ wykorzystywaniem w wielu gałęziach i działach prawa uchwał organizacji międzynarodowych.

Organizacja międzynarodowa, jako podmiot utworzony przez państwa na mocy umowy międzynarodowej, wszystkie swoje kompetencje, w tym kompetencje prawotwórcze, wywodzi de facto z umowy ją konstytuującej. Niemniej, przyczynami nieważności aktu instytucjonalnego organizacji międzynarodowej będą przypadki podjęcia tego aktu w sytuacji braku kompetencji lub z przekroczeniem nadanej kompetencji oraz $\mathrm{w}$ razie naruszenia podstawowych wymogów proceduralnych. W konsekwencji również akty ultra vires, jeżeli sa sprzeczne z prawem międzynarodowym i można je przypisać organizacji, moga być podstawą odpowiedzialności. Trzeba zaznaczyć, że organizacja międzynarodowa może de facto zostać pociągnięta do odpowiedzialności za akt swego organu, nawet jeśli organ ten działał, wykraczając poza swoje kompetencje. Tak więc można $\mathrm{z}$ dużą doza prawdopodobieństwa przyjąć, że warunkiem jest tu jednak, aby określony akt został podjęty przez organ organizacji działajacy w oficjalnej formie. Warto zaznaczyć, że operatywne wykonywanie zadań przez organizację międzynarodową może mieć więc tylko ograniczony zasięg. Jednakże i przy wykonywaniu funkcji operacyjnych podejmowanie decyzji stanowi nadrzędną treść działania właściwych organów organizacji. Charakter współczesnych stosunków międzynarodowych bowiem nie pozwala oczekiwać, że państwa zgodzą się na oddanie do dyspozycji organizacji międzynarodowej poważniejszych środków materialnych i personalnych, tak aby mogła ona nie tylko formułować swe decyzje, ale również sama je wykonywać.

mgr Matgorzata Rzeszutko

Uniwersytet Warszawski

\footnotetext{
${ }^{55}$ Kluczowa dyskusja dotycząca możliwych zmian normatywnych interwencji humanitarnej doprowadziła do powstania w $2001 \mathrm{r}$. projektu podstawowych zasad i celów interwencji, zob. The Responsibility to Protect. Report of the International Commission on Intervention and State Sovereignty, Ottawa 2001.
} 


\section{ULTRA VIRES ACTS IN THE LIGHT \\ OF INTERNATIONAL ORGANISATIONS LIABILITY}

\section{Summary}

The results of the analyses presented in this paper allow formulation of the following conclusions: of the key importance seems to be the answer to the question of what happens when a resolution is taken in violation of the provisions of the constitution of an organisation regarding the competence of making laws. It is worth noting that the possibility of bearing responsibility by international organisations for their acts contrary to international law is accepted without reservation. Therefore, the ultra vires acts, if contrary to international law, may be attributed to the organisation, and may subsequently give rise to liability. 